\title{
Momento de transição II
}

Este Editorial é a seqüência de outro, intitulado "Momento de transição", publicado na edição Nov/dez 2008 da Revista Brasileira de Medicina do Esporte. Naquela ocasião, sinalizamos claramente que a nossa missão à frente da RBME tinha um tempo determinado, até que asumíssemos a Presidência da Sociedade Brasileira de Medicina do Exercício e do Esporte, fato que ocorreu durante o 210 Congresso Brasileiro de Medicina do Esporte, realizado em maio último, em São Paulo.

Como convém a um período de interinidade, procuramos não realizar grandes modificações de "rota", mas simplesmente manter a trajetória ascendente da RBME. Nesse período, iniciamos a divisão dos artigos originais com dados de pesquisa pelas grandes áreas da Medicina do Esporte: "Clínica Médica no Exercício e no Esporte", "Aparelho Locomotor no Exercício e no Esporte" "Ciências do Exercício e do Esporte", visando uma melhor organização dos artigos publicados em cada edição.

Nesse período, a RBME obteve a indexação no Web of Science, maior indexador de periódicos científicos em todo o mundo. Este foi o resultado de um trabalho de longo prazo planejado e executado pelos editores anteriores, Drs. Antonio Cláudio Lucas da Nóbrega e Renata Castro, que com o atingimento dessa meta formalmente consideraram finalizada a sua missão à frente da RBME como editores.

Além disso, também nesse período realizamos a transição para o Sistema de Submissão On-Line do Scielo, consolidando essa parceria com esse importante indexador. Dos 197 títulos correntes do Scielo, apenas 37 periódicos têm hoje esse acesso. Desde o início de março, as submissões on-line da RBME passaram ser realizadas no endereço http://submission.scielo.br/index.php/rbme, com a desativação progressiva do site antigo, que permanecerá apenas para os artigos que já estavam em processo de revisão pelos pares.

Com a Atha Editora e com o novo patrocinador principal (Laboratório Zambon), foi bastante ampliada a visibilidade da RBME, que passou a uma tiragem de 5.000 exemplares, distribuídos em todo o Brasil, com uma perspectiva de médio prazo de auto-suficiência em termos financeiros, sem que haja mais a necessidade de subsídio por parte da Sociedade Brasileira de Medicina do Exercício e do Esporte.

Tivemos imensa satisfação com o aceite do Prof. Dr. Arnaldo José Hernandez, agora ex-Presidente da SBME, para assumir como Editor-Chefe da Revista Brasileira de Medicina do Esporte. A sua biografia humana, profissional e acadêmica não nos deixam a mínima dúvida quanto à sua capacidade, mérito e empenho em elevar a RBME a novos patamares, contemplando o planejamento da SBME para a próxima década.

Desta forma, consideramos finalizada a nossa curta missão à frente da RBME, a qual assumimos por solicitação do então Presidente da SBME, a quem - por mérito, fazemos questão de reiterar -"passamos o bastão" para conduzir a RBME nos próximos anos.

Dr. José Kawazoe Lazzoli

Presidente, Sociedade Brasileira de Medicina do Exercício e do Esporte

\section{Apenas mais um no revezamento}

Maior do que a honra e o orgulho de ser Editor-Chefe da Revista Brasileira de Medicina do Esporte, só a responsabilidade dessa função.

Você, caro leitor, sabe do crescimento e da importância acadêmica que este veículo atingiu ao longo dos anos. Isso só foi possível graças a uma cadeia de trabalho da qual várias pessoas participam ativamente. Essa cadeia é, na verdade, mais um círculo onde alguém ocupa o papel mais relevante em diferentes momentos. Neste instante você é, sem dúvida, essa pessoa. É para transmitir informação e conhecimento ao leitor que uma revista é feita, não para satisfazer as necessidades de publicação de nossos pesquisadores. Num breve instante o Editor-Chefe ocupa essa posição, quando define o que será divulgado, após a aprovação pelos pares. Todo o trabalho que antecede esse momento serve apenas para que ele aconteça.

Após todas as rotinas de uma publicação científica, é o produto final que coloca esta revista no patamar científico que a Sociedade Brasileira de Medicina do Exercício e do Esporte (SBME) pretende. O Editor-Chefe é quem deve zelar por essa missão de grande responsabilidade. Os Editores que nos antecederam cumpriram-na de forma exemplar, o que permitiu que atingíssemos patamares de indexação de grande relevância. Devemos sempre agradecer a cada um deles e aos demais colaboradores da RBME.

Coube a mim assumir essa função neste momento. Agradeço a confiança e espero corresponder aos anseios da SBME. Peço a Deus que assim o permita. 